\title{
Penanaman Karakter dalam Program Gerakan Literasi Sekolah di SMP Negeri 18 Padang
}

\author{
Zurahmi Dewi, Isnarmi \\ Program Studi Pendidikan Pancasila dan Kewarganegaraan \\ Universitas Negeri Padang \\ E-mail: zurahmidewi97@gmail.com
}

\section{ABSTRAK}

Artikel ini bertujuan untuk mendeskripsikan pelaksanaan penanaman karakter serta kendala-kendala penanaman karakter dalam program Gerakan Literasi Sekolah di SMP Negeri 18 Padang. Artikel ini dilatarbelakangi oleh banyaknya permasalahan yang berkaitan dengan merosotnya karakter peserta didik. Program Gerakan Literasi Sekolah ini merupakan Permendikbud nomor 23 tahun 2015 tentang penumbuhan budi pekerti melalui Gerakan Literasi Sekolah. Penelitian ini menggunakan penelitian kualitatif dengan metode deskriptif. Informan penelitiannya meliputi kepala sekolah, ketua gerakan literasi sekolah, guru-guru, petugas perpustakaan serta siswa-siswa SMP Negeri 18 Padang. Pengumpulan data melalui observasi, wawancara dan studi dokumentasi. Analisis data melalui tahapan yaitu pengumpulan data, reduksi data, penyajian data, penarikan kesimpulan. Hasil penelitian ini menunjukkan bahwa penanaman karakter dalam program Gerakan Literasi Sekolah di SMP Negeri 18 Padang ialah penanaman nilai karakter disiplin, kreatif, tanggung jawab, dan gemar membaca. Serta masih terdapatnya kendala-kendala pelaksanaan penanaman karakter dalam program Gerakan Literasi Sekolah diantaranya. Kebiasaan siswa yang kurang disiplin terhadap waktu, kemampuan berfikir kreatif peserta didik yang berbeda-beda, dan kurangnya rasa tanggung jawab siswa terhadap pengumpulan tugas, kurangnya waktu yang tersedia untuk membaca di sekolah dan kurangnya ketersediaan buku bacaan disekolah.

\section{Kata Kunci: nilai karakter, gerakan literasi sekolah, Padang}

\section{ABSTRACT}

This article aims to describe how the implementation of character planting in the School Literacy Movement program and the constraints of it in the School Literacy Movement program in SMP Negeri 18 Padang. This research is motivated by the many problems associated with the decline in the character of students. The School Literacy Movement Program is Permendikbud number 23 of 2015 concerning the growth of character through the School Literacy Movement. This study uses qualitative research with descriptive methods. The research informants included the school principal, head of the school literacy movement, teachers, library staff and students of Padang 18 Middle School. Data collection through observation, interviews and documentation studies. Data analysis through stages namely data collection, data reduction, data presentation, drawing conclusions. The results of this 
study indicate that the inculcation of character in the School Literacy Movement program at SMP Negeri 18 Padang is the inculcation of the values of disciplined, creative, responsible, and fond of reading characters. And there are still obstacles to the implementation of character planting in the School Literacy Movement program including. Habits of students who lack discipline in time, students 'ability to think creatively differently, and lack of students' sense of responsibility for the collection of assignments, lack of time available to read at school and lack of availability of reading books in school.

\section{Keywords : character value, school literacy movement, Padang city}

\section{PENDAHULUAN}

Saat ini Bangsa Indonesia sedang dihadapkan pada persoalan moralitas dan krisis karakter. Persoalan moralitas ditandai dengan banyaknya kondisi moral atau akhlak generasi muda yang tidak sesuai dengan nilai-nilai karakter bangsa Indonesia. Menurut Omeri (2015:465) pendidikan karakter mutlak diperlukan bukan hanya disekolah saja, tapi dirumah di lingkungan sosial. Sedangkan menurut Oktarina (2018) karakter sebagai sistem penanaman nilai-nilai karakter kepada warga sekolah meliputi komponen pengetahuan, kesadaran atau kemauan dan tindakan untuk melaksanakan nilai-nilai tersebut. Jadi pendidikan karakter merupakan salah satu upaya penting yang harus dilakukan sedari dini.

\begin{tabular}{lcr}
\multicolumn{2}{c}{ Pendidikan } & karakter \\
merupakan & upaya & untuk \\
menanamkan & nilai-nilai & kepada
\end{tabular}
peserta didik agar menjadi manusia yang berkarakter. Dalam UndangUndang Nomor 23 Tahun 2003 Pasal 3 menegaskan bahwa pendidikan nasional berfungsi mengembangkan kemampuan dan membentuk watak serta peradaban bangsa yang bermartabat dalam rangka mencerdaskan kehidupan bangsa. Pendidikan karakter bertujuan untuk mengembangkan potensi peserta didik agar menjadi manusia yang beriman dan bertakwa kepada Tuhan Yang Maha Esa, berakhlak mulia, sehat, berilmu, cakap, kreatif, mandiri dan menjadi warga negara yang demokratis serta bertanggung jawab. Oleh karena itu, pendidikan karakter dapat menjadikan peserta didik yang berakhlak mulia dan taqwa pada Tuhan Yang Maha Esa.

$$
\text { Pendidikan karakter }
$$

disekolah dapat dilakukan melalui program-program yang ada di sekolah. Salah satunya program Gerakan Literasi sekolah atau GLS. Menurut Permendikbud Nomor 23 Tahun 2015 tentang penumbuhan budi pekerti dapat dilaksanakan melalui Gerakan Literasi Sekolah. Sedangkan menurut Kemendikbud (2016:2) GLS berupaya menumbuhkembangkan budi pekerti peserta didik melalui pembudayaan ekosistem literasi sekolah yang diwujudkan dalam gerakan literasi sekolah, agar menjadi pembelajar sepanjang hayat. Jadi berdasarkan uraian diatas maka pendidikan karakter dapat 
ditanamkan melalui program Gerakan Literasi Sekolah.

GLS diharapkan mampu memicu dan berpengaruh pada sikap dan perilaku positif dikalangan peserta didik. Menurut Noven (2018:301) salah satu kegiatan yang dapat menanamkan perilaku positif dalam GLS adalah kegiatan literasi 15 menit membaca buku non pembelajaran yang bahan bacaannya berisi nilai-nilai seperti budi pekerti, cinta tanah air, kearifan lokal, nasional dan global mempunyai peran penting dalam menumbuhkan karakter siswa yang sesuai dengan perkembangan peserta didik. Sedangkan menurut Rahayu (2017:1062) bahwa dalam kegiatan literasi diharapkan dapat menumbuhkan sikap simpati dan empati siswa sehingga siswa dapat menerima suatu nilai yang pada akhirnya mengarahkan untuk berperilaku positif. Jadi berdasarkan pemaparan diatas bahwa GLS dapat meningkatkan karakter siswa melalui aktivitas membaca yang nantinya siswa dapat memilih mana perbuatan baik dan buruk.

GLS dapat membentuk karakter siswa di sekolah. Berdasarkan penelitian yang dilakukan oleh Wandasari (2017:340) tentang implementasi GLS sebagai pembentukan karakter mengatakan bahwa pembentukan karakter gemar membaca siswa dapat dilakukan melalui GLS yang dilakukan melalui pembiasaan membaca selama 15 menit setiap harinya. Selanjutnya dalam penelitian Rahayu (2017:1065) dengan judul penelitian tentang gerakan literasi sekolah sebagai upaya penumbuhan karakter siswa sekolah dasar bahwa penumbuhan karakter dalam kegiatan gerakan literasi sekolah dengan cara memaksimalkan interaksi antara guru dan siswa untuk menumbuhkan karakter bersahabat atau komunikatif, menata hasil karya literasi sehingga dapat menumbuhkan karakter kreatif dan memajang hasil karya siswa untuk menghargai prestasi siswa. Jadi pelaksanaan GLS dapat menumbuhan karakter pada siswa ke arah yang lebih baik.

SMP Negeri 18 Padang merupakan salah satu sekolah yang menerapkan pendidikan karakter melalui kegiatan GLS. Kegiatan GLS di SMP Negeri 18 Padang yang menanamkan karakter meliputi kegiatan membaca buku non pembelajaran selama 15 menit setiap pagi hari Rabu dan Sabtu sebelum pembelajaran dimulai. Kegiatan GLS di SMP Negeri 18 Padang merupakan kegiatan yang menanamkan karakter gemar membaca, disiplin, kreatif dan bertanggung jawab. Namun masih terdapatnya siswa yang rendah minat bacanya dan tidak disiplin dalam melaksanakan kegiatan literasi. Kurangnya rasa tanggung jawab siswa dalam menjaga karya literasi dan masih rendahnya daya kreativitas siswa untuk menghasilkan karya literasi. Hal ini disebabkan karena kurangnya karakter peserta didik disekolah.

Pentingnya artikel ini dibahas yaitu untuk mengetahui bagaimana penanaman karakter dalam program gerakan literasi sekolah di SMP Negeri 18 Padang. Alasan penulis memilih SMP Negeri 18 Padang karena sekolah ini merupakan sekolah pertama yang melaksanakan dan meluncurkan program Gerakan Literasi Sekolah di Kota Padang. SMP ini menjadi leader atau pelopor yang dapat menginspirasi sekolah-sekolah yang 
belum melaksanakan GLS di Kota Padang. Oleh karena itu pendidikan karakter penting dikaji dalam dunia pendidikan.

Berdasarkan uraian diatas maka penulis tertarik untuk membahas artikel tentang penanaman karakter dalam program GLS di SMP Negeri 18 Padang. Nilai karakter yang akan diteliti dalam pelaksanaan program GLS di SMP Negeri 18 Padang diantaranya nilai karakter disiplin, nilai karakter kreatif, nilai karakter tanggung jawab dan nilai karakter gemar membaca.

\section{METODE PENELITIAN}

Jenis penelitian ini merupakan penelitian kualitatif dengan menggunakan metode deskriptif yang bertujuan untuk mengambarkan, mendeskripsikan serta menjelaskan peristiwa berkaitan dengan penanaman karakter dalam program gerakan literasi sekolah. Lokasi penelitian ini dilakukan di SMP Negeri 18 Padang. Lokasi ini diambil berdasarkan observasi awal bahwasanya sekolah ini merupakan sekolah pertama yang melaksanakan launching gerakan literasi sekolah di Kota Padang. Informan penelitian diperoleh melalui teknik purposive sampling. Informan dalam penelitian ini adalah kepala sekolah, ketua gerakan literasi sekolah, guru-guru, petugas perpustakaan, serta siswasiswi SMP Negeri 18 Padang.

Teknik pengumpulan data dalam penelitian ini melalui observasi, wawancara dan dokumentasi. Teknik observasi yang peneliti lakukan untuk mengamati penanaman karakter dalam gerakan literasi sekolah di SMP Negeri 18 Padang. Sedangkan teknik wawancara yang peneliti lakukan menggunakan pedoman wawancara, kemudian dokumentasi yang berupa foto atau gambar. dalam menguji keabsahan data penelitian, peneliti mengunakan triangulasi teknik. Serta untuk analisis data dilakukan dengan pengumpulan data, reduksi data, penyajian data, penarikan kesimpulan.

\section{HASIL DAN PEMBAHASAN}

\section{Pelaksanaan Penanaman Karakter dalam Program Gerakan Literasi Sekolah di SMP Negeri 18 Padang}

Karakter merupakan sikap atau perilaku yang ada pada diri manusia. Karakter bagian dari tabiat, sifat-sifat kejiwaan, akhlak, watak, atau budi pekerti yang membedakan seseorang dengan yang lainnya. Menurut Samrin (2016:123) mengatakan bahwa nilainilai perilaku manusia yang universal meliputi seluruh aktivitas manusia, baik dalam rangka berhubungan dengan Tuhan, dengan dirinya, dengan sesama manusia, maupun dengan lingkungannya yang terwujud dalam pikiran, sikap, perasaan, perkataan, dan perbuatan. Jadi karakter ialah perilaku yang penting dimiliki oleh manusia dalam kehidupan sehari-hari.

Pelaksanaan GLS harus mengikuti langkah-langkah tertentu sehingga dapat mengembangkan kemampuan siswa. Dengan tujuan agar siswa mengerti dan memahami, merasakan sesuatu, dan dapat menimbulkan tindakan, sehingga dapat menumbuhkan rasa simpati dan empati siswa. Untuk menerima suatu nilai yang pada akhirnya mengarahkan siswa untuk menunjukkan suatu karakter dalam bentuk cara berfikir, bertindak dan berperilaku positif. Rahayu (2017) 
mengatakan siswa menjadikan buku bacaannya sebagai pedoman dalam bersikap. Saat dilapangan peneliti melihat siswa sangat fokus membaca buku bacaannya, ada yang membaca buku tentang "Menjadi Pribadi Berkarakter", "Lalai waktu”, "Rahasia Sukses Berhijrah (sukses meraih mimpi, produktifkan diri, dekat dengan Ilahi), Bahaya Narkoba", dan judul lainnya. Hal ini bertujuan agar buku bacaan yang dibaca oleh siswa akan berdampak kepada perilaku mereka dalam bersikap.

Pembentukan karakter dapat dilakukan dalam kegiatan GLS. Menurut Budi (2017) penanaman nilainilai karakter siswa melalui gerakan literasi sekolah dasar merupakan proses humanisasi pendidikan dan upaya menumbuh kembangkan budi pekerti, karakter siswa di sekolah sehingga menjadikan pembelajar sepanjang hayat yang berkarakter baik. Sedangkan Menurut Ningrum (2019) kegiatan literasi sesuai dengan pendidikan karakter. Hal ini karena literasi merupakan perwujudan pendidikan karakter individu. Oleh karena itu gerakan literasi sekolah salah satu tindakan dalam mengatasi permasahan karakter.

Guru ialah salah satu aspek terpenting dalam penanaman nilainilai karakter bagi siswa di sekolah. Jika hal ini tidak maksimal tentu menjadi bumerang bagi lembaga pendidikan dan guru itu sendiri. Ilmu mendidik harus maksimal dimiliki oleh seorang guru. Upaya membangun perubahan di sekolah melalui literasi menjadi penting dilaksanakan. Karena adanya informasi dan pengetahuan yang berkembang tanpa batas. Menurut Khalamah (2017), intisari dari program GLS dianggap dapat dijadikan sarana yang baik dalam penanaman nilai-nilai karakter sebagai manifestasi tujuan pendidikan. Oleh karena itu penanaman nilai-nilai karakter siswa melalui gerakan literasi sekolah sebagai upaya dalam melakukan perubahan dalam pendidikan disekolah.

Temuan penanaman karakter dalam kegiatan gerakan literasi sekolah di SMP Negeri 18 Padang ini berupa pembiasaan membaca dan menulis buku non pelajaran selama 15 menit setiap pagi hari Rabu dan Sabtu sebelum pembelajaran dimulai. Kegiatan literasi meliputi memilih buku bacaan, membuat jurnal literasi, menciptakan lingkungan kaya teks, menghasilkan kreativitas literasi seperti menciptakan buku, menjadikan siswa yang gemar membaca dan bertanggung jawab akan karyanya. Oleh karena itu penanaman karakter dalam GLS penting dilakukan agar terciptanya peserta didik yang berkarakter kreatif.

Dalam kegiatan GLS di SMP Negeri 18 Padang diperlukan fasilitas agar menunjang kegiatan tersebut. Salah satu fasilitasnya adalah pojok literasi. Setiap ruangan di SMP Negeri 18 Padang mempunyai pojok literasi. Pojok literasi tersedia diruangan kepala sekolah, di ruangan majelis guru, tata usaha, perpustakaan, dan di pintu masuk SMP Negeri 18 Padang serta di setiap sudut kelas disediakan pojok literasi. Oleh karena itu, penananam karakter dalam kegiatan gerakan literasi sekolah harus disediakannya fasilitas pendukung kegiatan literasi agar kegiatan tersebut terlaksana secara optimal. Adapun Pelaksanaan Penanaman karakter dalam program gerakan literasi sekolah di SMP Negeri 18 Padang 
adalah karakter disiplin, karakter kreatif, karakter tanggung jawab dan karakter gemar membaca.

\section{a. Menanamkan Karakter Disiplin}

Karakter disiplin adalah tindakan yang menunjukkan perilaku tertib dan patuh pada berbagai ketentuan dan peraturan. Bentuk penanaman karakter disiplin dalam program gerakan literasi sekolah di SMP Negeri 18 Padang ialah membiasakan siswa membaca 15 menit sebelum kegiatan pembelajaran rutin dilakukan setiap pagi hari Rabu dan Sabtu. Karakter disiplin dalam GLS di tanamkan agar siswa dapat mengahargai waktu yang telah diberikan. Dalam hal ini siswa dilatih untuk disiplin terhadap waktu agar bisa memanfaatkan waktu 15 menit untuk berliterasi.

Kegiatan literasi di SMP Negeri 18 Padang dapat meningkatkan karakter disiplin terhadap siswa. Menurut Wirawan (2018) kegiatan gerakan literasi sekolah disediakan selama 15 menit sebelum pembelajaran. Siswa harus memaksimalkan waktu 15 menit untuk kegiatan membaca dan menulis (literasi). Jika ditemukan siswa yang tidak tepat waktu dalam mengumpulkan jurnal literasi guru akan memberikan sanksi tegas berupa penandaan nama dalam buku penilaian siswa dan tidak memberikan tanda tangan pada jurnal literasi siswa itu sendiri. Diperkuat juga dengan penelitian yang dilakukan oleh Hidayati (2017) bahwasanya internalisasi nilai karakter disiplin dapat ditanamkan melalui kegiatan Gerakan Literasi Sekolah dengan menetapkan waktu berliterasi. Oleh karena itu pentingnya penanaman karakter disiplin dalam kegiatan gerakan literasi sekolah agar siswa terlatih untuk bersikap disiplin.

\section{b. Menanamkan karakter Kreatif}

Program gerakan literasi sekolah dapat menanamkan karakter kreatif pada siswa. Karakter kreatif ialah kemampuan untuk bisa memadukan berbagai informasi dengan cara baru, guna menemukan solusi dari masalah, menciptakan karya seni. Menurut Utami, Ratnasari Diah (2017) tujuan dalam penanaman karakter kreatif dalam GLS adalah mewujudkan peserta didik yang kreatif yaitu siswa yang cerdas dan berkarakter. Bentuk penanaman karakter kreatif dalam program gerakan literasi sekolah di SMP Negeri 18 Padang diantaranya ialah: siswa membuat karya buku dalam satu kelas atau yang disebut dengan satu buku satu kelas (SABUSAKEL).

Menurut Ichsan, Ahmad Shofiyuddin (2018) Sabusakel ialah singkatan dari satu buku satu kelas, sekolah menargetkan masing-masing kelas mampu menulis buku, didalam SABUSAKEL ada berbentuk karya puisi, pantun, cerita inspirasi, motivasi bahkan cerpen, bagi siswa yang memiliki bakat menulis, dengan kegiatan inilah bakatnya tersalurkan, tidak hanya itu hasil karya-karya kelas mereka dilombakan diakhir semester kenaikan kelas atau pada saat classmetting, hal ini bertujuan untuk memotivasi siswa untuk selalu menghasilkan karya-karya menarik agar menumbuhkan karakter kreatif pada peserta didik.

Siswa membuat pojok literasi di sudut kelas sebagai bentuk kreatifitas siswa. Berdasarkan hasil pengamatan 
dan wawancara dengan pihak sekolah bahwa sekolah telah membuat pojok literasi dan membuat lingkungan sekolah yang kaya akan teks. Menurut Lestari, Fajriati Dwi (2018) pojok baca menjadi salah satu upaya untuk menciptakan lingkungan fisik sekolah menjadi ramah literasi, yakni dengan cara membuat siswa mampu memperoleh pengetahuan melalui buku bacaan atau bahan belajar lain di sudut kelas dengan mudah. Pojok literasi tersebut diberi nama pojok baca kelas.

Pojok baca kelas bagian dari hasil kreatifitas siswa karena siswa dikelas itu sendiri yang membentuk pojok literasinya dengan memberikan hiasan yang menarik, guru-guru hanya mengarahkan saja semua siswa wajib menjaga kebersihan dan keindahan pojok literasinya, sepulang sekolah siswa yang piket harus menata dan merapikan kembali buku-buku yang ada di pojok literasi. Pojok literasi adalah tempat letak buku bacaan siswa. Pada pojok literasi disediakan buku-buku bacaan tentang pendidikan, ilmu pengetahuan, bukubuku motivasi dan inspirasi serta buku lainnya. Setiap kelas di SMP Negeri 18 Padang mempunyai pojok literasi dengan beragam bentuk dan hiasan yang unik dan berbeda. Hal ini bertujuan untuk menarik siswa untuk menumbuhkan kreatifitas yang ada pada dirinya.

Siswa dilatih untuk berkreatifitas dalam menulis jurnal literasi. Menurut Nurchasanah (2016) jurnal literasi atau jurnal membaca harian siswa ialah instrumen berupa tabel rekaman capaian membaca peserta didik dilakukan lima belas menit setiap hari. Sedangkan Menurut Jhayanti, Rindah (2018) jurnal literasi bermanfaat untuk membantu peserta didik dan guru dalam memantau jenis dan jumlah buku yang dibaca untuk kegiatan membaca lima belas menit. Kegiatan gerakan literasi sekolah ini tidak hanya melatih siswa untuk terbiasa membaca tetapi juga melatih kemampuan menulis siswa.

Untuk menunjang hal itu pihak sekolah menyediakan jurnal literasi siswa, agar kemampuan menulis mereka dapat disalurkan sehingga mereka bisa berkreatifitas dalam menulis baik menulis tentang buku, maupun menulis cerpen, dan novel. Jurnal literasi ini disediakan oleh pihak sekolah bertujuan untuk menarik minat siswa untuk menulis. Hal ini dibiasakan oleh siswa, sehingga siswa menjadi terampil dalam menulis. Jurnal literasi sebagai alat kontrol baca siswa dimana selesai kegiatan membaca siswa diharuskan membuat jurnal literasi mengenai kandungan yang terdapat dalam buku yang mereka baca. Hal ini dapat melatih siswa dalam mengembangkan kreatifitas siswa dalam menulis.

Salah satu bentuk kreatifitas siswa di SMP Negeri 18 Padang ini adalah setiap kelas siswa membuat selfi literasi. Siswa membuat selfi literasi di kelas sebagai bentuk kreatifitas dalam kegiatan GLS. Selfi literasi adalah kegiatan berfoto bermanfaat. Apabila ada kegiatan gotong royong, kegiatan kumpul bersama wali kelas, kegiatan diskusi kelas dan kegiatan lainnya pada saat kegiatan itu difoto oleh tim selfi literasi. Hasil foto itu di print dan ditempel di dinding kelas di tulis dibawah foto tersebut berupa katakata motivasi, inspirasi yang menggambarkan foto selfi literasi. Menurut Alfarik, Asif (2017) selfi 
literasi adalah kegiatan selfi yang berkaitan dengan kegiatan kelas dan hasil foto selfinya dipajang di dalam kelas dengan menuliskan kata-kata motivasi dalam foto tersebut hal ini bertujuan untuk menarik minat peserta didik agar mencintai dunia literasi. Oleh karena itu kegiatan literasi tidak hanya membiasakan membaca tetapi juga membiasakan siswa untuk berkarya.

Siswa membuat pohon citacita/pohon literasi sebagai bentuk kreatifitas siswa dalam kegiatan gerakan literasi sekolah. Menurut Ramadhani, Aulia Widya (2019) pohon literasi sebagai bentuk penanaman karakter kreatif dalam gerakan literasi sekolah karena pohon ini berisi rangkuman dari buku yang dibaca siswa, atau menuliskan cita-cita siswa. Sedangkan menurut Priyani, Niken Eka (2018) pohon literasi bertujuan untuk meningkatkan motivasi siswa untuk membaca buku. SMP Negeri 18 Padang menanamkan karakter kreatifitas pada siswa melalui kegiatan gerakan literasi sekolah. Salah satunya siswa berkreasi dalam membuat pohon literasi dikelasnya masingmasing.

Pembuat pohon literasi ini ialah semua siswa dikelas membuat gambar pohon pada kertas karton dan kertas plano atau membuat pohon literasi dengan menggunakan ranting asli, dan daun-daunnya dengan kertas-kertas warna atau kertas yang sudah diwarnai. Kemudian pada daun yang terbuat dari kertas warna tersebut ditulis nama, cita-cita serta kata-kata motivasi atau deskripsi hasil buku bacaan yang dibaca masing-masing. Hal ini bertujuan untuk merangsang siswa untuk berkreativitas dalam berliterasi.

Tidak semua sekolah yang menyediakan fasilitas literasi. Seperti halnya di SMP Negeri 12 Padang hanya menyediakan pojok literasi saja, tidak merangsang siswa untuk kreatif dalam berliterasi. SMP Negeri 12 Padang tidak mewajibkan siswanya untuk menulis jurnal literasi bahkan sekolahnya belum menyediakan jurnal literasi sebagai penunjang berliterasi. Dalam kegiatan gerakan literasi sekolah membaca dan menulis merupakan kegiatan yang sejalan agar terciptanya tujuan dari program gerakan literasi sekolah tersebut.

Menurut kemendikbud (2016:14) kegiatan literasi 15 menit membaca dan menulis perlu di dukung oleh lingkungan yang kaya teks seperti adanya poster-poster yang terkait kampanye membaca yang bertujuan menumbuhkan cinta pengetahuan dan budi pekerti, dinding kata, buku dan informasi lain, karya karya peserta didik berupa tulisan, gambar atau grafik. Oleh karena itu, pentingnya sekolah menyediakan fasilitas literasi untuk menunjang program Gerakan Literasi Sekolah.

c. Menanamkan Karakter Tanggung Jawab

Tanggung jawab bagian dari karakter penting yang harus dimiliki oleh manusia. Karakter tanggung jawab adalah sikap dan perilaku seseorang untuk melaksanakan tugas dan kewajiban yang seharusnya dia lakukan terhadap Tuhan Yang Maha Esa, diri sendiri, masyarakat, lingkungan (alam, sosial, dan budaya), dan negara. Menurut Shaleh (2014) 
tanggung jawab sebagai ciri manusia beradab. Manusia bertanggung jawab karena ia menyadari akibat baik atau buruk dari perbuatannya itu. Oleh karena itu pentingnya penanaman karakter tanggung jawab pada diri manusia.

Karakter tanggung jawab dapat ditanamkan dalam kegiatan GLS. Bentuk penanaman karakter tanggung jawab pada siswa melalui kegiatan literasi sekolah di SMP Negeri 18 Padang ialah dalam hal pengumpulan tugas jurnal baca harian siswa atau jurnal literasi siswa dengan tepat waktu. Agar melatih siswa untuk bertanggung jawab pada dirinya sendiri. Apabila siswa terlambat mengumpulkan buku jurnal baca harian, atau tidak sesuai dengan waktu yang telah ditentukan, maka siswa harus menerima konsekuensinya ialah jurnal baca hariannya tidak diperiksa oleh guru. Guru melatih rasa tanggung jawabnya dalam mengumpulkan tugas secara on time.

(2017) pembentukkan karakter tanggungjawab siswa secara implicit dilaksanakan dalam gerakan literasi sekolah melalui pengumpulan tugas jurnal literasi dengan tepat waktu. Hal ini dapat melatih siswa untuk bertanggung jawab pada dirinya sendiri maupun pada orang lain. Karakter tanggung jawab siswa ini akan terbentuk seiring dengan pembiasaan yang dilakukan secara terus menerus. Siswa dilatih juga untuk bertanggung jawab dalam menjaga, merawat semua yang ada dikelasnya termasuk menjaga hasil karya siswa dari gerakan literasi sekolah seperti pohon literasi, selfi literasi, pojok baca, dan mading, pohon literasi/pohon cita-cita, selfi literasi. Hal ini bertujuan untuk menanamkan rasa tanggung jawab siswa baik untuk dirinya maupun dengan orang lain.

d. Menanamkan Karakter Gemar Membaca

Gemar membaca merupakan salah satu bentuk manusia yang berkarakter. Menurut Ariyanti (2019) Gemar membaca ialah kebiasaan menyediakan waktu untuk membaca berbagai bacaan yang memberikan kebajikan bagi dirinya secara teratur dan berkelanjutan untuk menemukan informasi dan memperluas wawasan bagi diri pembaca. Sedangkan Respati (2018) bahwa penanaman karakter gemar membaca dapat ditanamkan melalui kegiatan Gerakan Literasi Sekolah dengan metode 15 menit membaca buku setiap paginya. Penumbuhan budi pekerti gemar membaca oleh pemerintah melalui GLS menjawab persoalan rendahnya minat baca masyarakat Indonesia.

Sekolah di Indonesia sudah mulai menggalakkan karakter gemar membaca melalui kegiatan gerakan literasi sekolah agar membentuk peserta didik yang berkarakter. Selanjutnya menurut Satrio (2017), program GLS membiasakan anak gemar membaca menjadi salah satu contoh dimana setiap anak selalu dilatih dalam berfikir kritis, mampu memahami suatu persoalan, dapat menuangkan sesuatu dalam bentuk tulisan. Oleh karena itu penanaman karakter gemar membaca sudah seharusnya ditanamkan dalam diri manusia.

Penanaman karakter gemar membaca dapat dilakukan dalam kegiatan gerakan literasi sekolah. Bentuk penanamkan karakter gemar 
membaca pada siswa dalam program gerakan literasi sekolah di SMP Negeri 18 Padang ialah membiasakan siswa membaca selama 15 menit sebelum pembelajaran setiap pagi hari rabu dan sabtu atau dua kali dalam seminggu. Dalam kegiatan literasi disediakan lingkungan kaya teks untuk menunjang kegiatan tersebut. Seperti membuat poster-poster ajakan membaca, poster cara bersikap, poster yang berupa kata-kata motivasi yang bisa di baca oleh murid. Sekolah juga menyediakan pojok baca yang berisi buku-buku bacaan disetiap sudut kelas, dan setiap sudut sekolah. Siswa bebas kapan saja membaca buku karena buku telah tersedia di pojok baca sudut kelas, sudut sekolah. Hal ini dibiasakan pada siswa sehingga siswa menyukai, mencintai dunia membaca yang nantinya siswa menjadi gemar membaca.

Hal ini sesuai dengan hasil penelitian yang dilakukan oleh Lea Sakti Mitasari (2017) bahwa kegiatan gerakan literasi sekolah dapat memotivasi siswa untuk menyukai kegiatan membaca dan menulis. Sedangkan Menurut Julandi, Galant Irma (2018) upaya sekolah dalam menumbuhkan karakter gemar membaca pada siswa melalui tiga tahap mengenalkan, melakukan aksi dan memotivasi agar penumbuhkan karakter gemar membaca dapat diterima siswa. Oleh karena itu untuk menumbuhkan karakter gemar membaca siswa sekolah harus menyediakan fasilitas yang menunjang kegiatan Literasi Sekolah agar terciptanya warga sekolah yang gemar membaca.
Volume 1 No. 42018

\section{Kendala Pelaksanaaan Program Gerakan Literasi Sekolah di SMP Negeri 18 Padang}

Penanaman karakter dalam program gerakan literasi sekolah di SMP Negeri 18 Padang sudah berjalan dengan baik. Namun pada pelaksanaannya masih terdapat kendala diantaranya sebagai berikut.

a. Karakter Disiplin

Kendala penanaman karakter disiplin dalam program gerakan literasi sekolah yaitu sikap tidak disiplin dirumah terbawa kesekolah. Dan siswa terkadang selalu mengulangi kesalahan yang sama. Seperti tidak disiplin dalam waktu literasi, misalnya tidak tepat waktu dalam mengumpulkan jurnal literasi meskipun sudah mendapat teguran bahkan hukuman dari guru berupa penandaan nama siswa dalam buku penilaian siswa.

\section{b. Karakter Kreatif}

Kendala penanaman karakter kreatif dalam program gerakan literasi sekolah yaitu kemampuan berfikir kreatif peserta didik yang berbedabeda ada yang bagus dibidang akademik namun kurang dibidang psikomotor, keterampilan atau kreatifitas begitupun sebaliknya. Oleh karena itu kemampuan berfikir kreatif siswa tidak bisa disamaratakan.

\section{c. Karakter Gemar Membaca}

Kendala penanaman karakter gemar membaca dalam Program Gerakan Literasi Sekolah ialah kurangnya waktu yang tersedia untuk membaca di sekolah, kurangnya Ketersediaan buku bacaan disekolah, kurangnya motivasi siswa untuk membaca sehingga mengakibatkan 
masih rendahnya minat baca siswa di SMP Negeri 18 Padang.

d. Karakter Tanggung Jawab

Kendala penanaman karakter tanggung jawab dalam kegiatan gerakan literasi sekolah yaitu kurangnya rasa percaya diri siswa terhadap siswa terhadap tugas jurnal literasi yang mereka buat. Sehingga ia malu untuk mengumpulkan tugas jurnal literasinya. Masih ditemukannya siswa yang kurang bertanggung jawab terhadap tugas jurnal literasi yang telah diberikan oleh guru dengan waktu berliterasinya ditentukan 15 menit sebelum pembelajaran dimulai.

Masih ada siswa yang terlambat mengumpulkan tugas jurnal literasi lewat dari batas waktu yang telah ditentukan artinya masih kurang rasa tanggung jawab siswa terhadap tugas jurnal literasi. Dimana tugas merupakan bagian dari perintah, amanah yang harus dipertanggung jawabkan oleh siswa dalam menyelesaikannya sesuai dengan waktu yang telah diperintahkan. Guru memberikan teguran dan hukuman bagi siswa yang melanggar aturan yang telah ditetapkan dengan menandai namanya didalam buku penilaiannya bahwasanya kurang rasa tanggung jawabnya terhadap tugas yang diberikan. Hal ini dilakukan supaya siswa menjadi pribadi bertanggung jawab baik untuk dirinya sendiri maupun pada orang lain.

\section{KESIMPULAN}

Pelaksanaan penanaman karakter dalam program gerakan literasi sekolah di SMP Negeri 18 Padang ialah penanaman nilai karakter disiplin, nilai karakter kreatif, nilai karakter tanggung jawab, bertanggung jawab nilai karakter gemar membaca. Kendala-kendala pelaksanaan penanaman karakter dalam program GLS di SMP Negeri 18 Padang diantaranya: Kebiasaan siswa yang kurang disiplin terhadap waktu, kemampuan berfikir kreatif peserta didik yang berbeda-beda dan kurangnya rasa tanggung jawab siswa terhadap pengumpulan tugas, kurangnya waktu yang tersedia untuk membaca di sekolah dan kurangnya ketersediaan buku bacaan disekolah.

Peneliti berharap kedepannya kepala sekolah di SMP Negeri 18 Padang mencarikan bantuan ke pihak yang berwenang untuk menyediakan buku bacaan lebih banyak lagi. Hal ini bertujuan agar program GLS ini terlaksana dengan baik. Diharapkan kepala sekolah lebih memperhatikan dan mengawasi jalannya program GLS. Kepala sekolah hendaknya lebih menekankan lagi kepada guru-guru, pustakawan dan seluruh elemen sekolah untuk membaca saat kegiatan GLS agar terbentuknya sekolah yang berkarakter.

\section{DAFTAR PUSTAKA}

Anwar, Shabri Shaleh. 2014. Tanggung Jawab Pendidikan Dalam Perspektif Psikologi Agama. Jurnal ilmiah Psikologi, 1(1):14

Ariyanti. 2019. Implementasi Gerakan Literasi Sekolah (GLS) Sebagai Pembentuk Pembentuk Pendidikan Karakter. Jurnal Pendidikan, 1(1)

Batubara, Hamdan Husein. 2018. Implementasi Program Gerakan Literasi Sekolah di

Sekolah Dasar Negeri Gugus Sungai Miai Banjarmasin. Jurnal Pendidikan Sekolah 
Journal of Civic Education (ISSN: 2622-237X)

Volume 1 No. 42018

Dasar,1(4):17. P-ISSN 2540-9093. E-ISSN 2503-0558.

Departemen Pendidikan Nasional. 2010. Pendidikan Karakter Teori \& Aplikasi. Jakarta: Direktorat Jenderal Manajemen Pendidikan Dasar dan Menengah Kementerian Pendidikan Nasional.

Direktorat Jenderal Pendidikan Dasar dan Menengah Kementerian Pendidikan dan Kebudayaan. 2016. Panduan Gerakan Literasi Sekolah di Sekolah Menengah Pertama. Jakarta: Direktorat Jenderal Pendidikan Dasar dan Menengah Kementerian Pendidikan dan Kebudayaan.

Hendrawan, Budi. 2017. Kajian Aplikatif Penanaman nilai-nilai karakter siswa melalui Gerakan Literasi Sekolah di Sekolah Dasar Berdasarkan Perspektif Pedagogik Kritis. Jurnal Pendidikan dan Pembelajaran di Sekolah Dasar, 1(2)

Hidayati, Reny Nuril. 2017. "Internalisasi nilai-nilai pendidikan Karakter Dalam Gerakan Literasi Sekolah Pada Siswa Kelas 2 di Sekolah Dasar Muhammadiyah 9 Kota Malang". Skripsi. Malang. Fakultas Ilmu Tarbiyah dan Keguruan Universitas Islam Negeri Maulana Malik Ibrahim Malang.

Imanugroho, Satrio. 2017. Program Gerakan Literasi Sekolah Dalam Menumbuhkan Minat Baca Peserta didik SDN Kuripan Lor 01 Kota Pekalongan.

Julandi, Galant Irma. 2018. Upaya Sekolah Menumbuhkan Karakter Gemar Membaca Siswa di SMK Negeri 1 Sidoarjo.
Jurnal Kajian Moral dan Kewarganegaraan, 06 (3):383

Mitasari. Lea Sakti. 2017. "Peran Kegiatan Literasi Dalam Meningkatkan Minat Membaca dan Menulis Siswa Kelas Atas Di SD Gumpang 1". Skripsi. Surakarta. Fakultas Keguruan dan Ilmu Pendidikan Universitas Muhammadiyah Surakarta.

Nugroho, Alfian Handina. 2016. Implementasi Gemar Membaca Melalui Program Pojok Baca Dalam Mata Pelajaran IPS Pada Siswa Kelas VIII Di SMP Negeri 2 Sumber. Jurnal Edueksos, 5 (2):189

Oktarina, Ary. 2018. Pendidikan Karakter Gemar Membaca Melalui Program Literasi di SDN Golo Yogyakarta. Jurnal Pendidikan Guru Sekolah Dasar. 7(30):2943-2944.

Omeri, Nopan, 2015. Pentingnya Pendidikan Karakter Dalam Dunia Pendidikan. Jurnal Manajer Pendidikan, 9 (3):465

Peraturan Menteri Pendidikan dan

Kebudayaan Republik

Indonesia Nomor 23 Tahun

2015. Penumbuhan Budi

Pekerti.

Rahayu, Agustina Ratih. dkk. 2017.

Gerakan Literasi Sekolah

Sebagai Upaya

PenumbuhanKarakter Siswa

Sekolah Dasar. Jurnal

Transformasi Pendidikan Abad 21, 15(7):1062

Respati, Choiri Bayu. (2018) Implementasi Gerakan Literasi Sekolah Dalam Menanamkan Karakter Gemar Membaca Siswa Kelas Tinggi di SD Negeri 1 Sawahan. Skripsi. Surakarta. 
Fakultas Keguruan dan Ilmu Pendidikan Universitas Muhammadiyah Surakarta.

Samrin, 2016. Pendidikan Karakter (Sebuah Pendekatan Nilai). Jurnal Al-Ta'dib, 9(1)

Undang-Undang Republik Indonesia Nomor 23 Tahun 2003. Sistem Pendidikan Nasional

Wandasari, Yulisa. 2017. Implementasi Gerakan Literasi Sekolah (GLS) SebagaiPembentukkan

Pendidikan Berkarakter.Jurnal Manajemen, Kepemimpinan dan SupervisiPendidikan, 1(1):330-331

Wirawan, Noven Handani. 2018. Implementasi Gerakan Literasi Sekolah di SMP Negeri 4 Kota Bengkulu. Jurnal Ilmiah Korpus. 3(2): 301 